OPEN ACCESS

Edited by:

Huaxi Yi,

Ocean University of China, China

Reviewed by:

Xin Lu,

Northwest $A$ and $F$ University, China

Fei Liu,

Northeast Agricultural

University, China

Gang Wang,

Jiangnan University, China

*Correspondence:

Ping $\mathrm{Li}$

ping-biology@outlook.com

Qing Gu

guqing2002@hotmail.com

Specialty section:

This article was submitted to Nutritional Immunology,

a section of the journal

Frontiers in Nutrition

Received: 17 May 2021

Accepted: 21 June 2021

Published: 23 July 2021

Citation:

Dai M, Li Y, Xu L, Wu D, Zhou Q, Li P and $G u Q$ (2021) A Novel Bacteriocin From Lactobacillus Pentosus ZFM94 and Its Antibacterial Mode of Action.

Front. Nutr. 8:710862

doi: 10.3389/fnut.2021.710862

\section{A Novel Bacteriocin From Lactobacillus Pentosus ZFM94 and Its Antibacterial Mode of Action}

\author{
Mengdi Dai, Yanran Li, Luyao Xu, Danli Wu, Qingqing Zhou, Ping Li* and Qing Gu* \\ Key Laboratory for Food Microbial Technology of Zhejiang Province, College of Food Science and Biotechnology, Zhejiang \\ Gongshang University, Hangzhou, China
}

Bacteriocins are bioactive antimicrobial peptides synthesized in the ribosome of numerous bacteria and released extracellularly. Pentocin ZFM94 produced by Lactobacillus pentosus (L. pentosus) ZFM94, isolated from infant feces with strong antibacterial activity, was purified by ammonium sulfate precipitation, dextran gel chromatography, and reverse-phase high-performance liquid chromatography (RP-HPLC). The molecular mass of the purified bacteriocin was 3,547.74 Da determined by matrix-assisted laser desorption/ionization time-of-flight mass spectrometry (MALDI-TOF MS). Pentocin ZFM94 exhibited broad-spectrum antimicrobial activity against tested Gram-positive and Gram-negative bacteria, and the minimal inhibitory concentrations (MICs) of Micrococcus luteus (M. luteus) 10,209, Staphylococcus aureus (S. aureus) D48, and Escherichia coli (E. coli) DH5 $\alpha$ were 1.75, 2.00, and $2.50 \mu \mathrm{m}$, respectively. Pentocin ZFM94 was heat-stable $\left(30 \mathrm{~min}\right.$ at $\left.80^{\circ} \mathrm{C}\right)$ and showed inhibitory activity over a wide $\mathrm{pH}$ range (5.00-7.00). It could be degraded by trypsin and pepsin, but not by amylase, lysozyme, lipase, and ribonuclease A. Fluorescence leakage assay showed that pentocin ZFM94 induced disruption of the cell membrane and caused leakage of cellular content. Furthermore, lipid II was not an antibacterial target of pentocin ZFM94. This study laid the foundation for further development and utilization of $L$. pentosus ZFM94 and its bacteriocin.

Keywords: bacteriocin, purification, pentocin ZFM94, antibacterial activity, mode of action

\section{INTRODUCTION}

Bacteriocins are ribosomally synthesized peptides that in most cases they exhibit antibacterial activity against bacteria that are closely related to the producing bacteria. As for food corruption, the commonly used method is to add preservatives. Although, the toxicity of the preservatives now used is low, the toxicity accumulates and damages the body when taken in excess. Non-toxic natural preservatives solve this problem perfectly. The bacteriocins are of very high perspective because they may not only be used for food biopreservation but also have the potential to be utilized as antibiotics, exploited in animal healthcare and marine environment (1). Bacteriocins are usually divided into four groups (2). Class I bacteriocins, known as lantibiotic, generally have a molecular weight of $<5 \mathrm{kDa}$ (3), such as lanthionine, $\beta-12$ methyllanthionine, dehydrobutyrine, dehydroalanine, and labyrinthine. Class I is further subdivided into class Ia (lantibiotics), class Ib (labyrinthopeptins), and class Ic (sanctibiotics). Nisin is a most popular class I bacteriocin (4). Class II bacteriocins are called non-lantibiotics with molecular weight $<10 \mathrm{kDa}$ (5), which contain 
30-60 amino acids with thermal stability, and Class II bacteriocins can be further subdivided into class IIa (pediocin-like bacteriocins), class IIb (two-peptide unmodified bacteriocins), class IIc (circular bacteriocins), and class IId (unmodified, linear, and non-pediocin-like bacteriocins). Pediocin-like bacteriocins are the most dominant class IIa bacteriocins (4). Class III bacteriocins are non-lantibiotics with heat sensitivity, and their molecular weight is generally $>30$ $\mathrm{kDa}$ (6). Colicin is one of the examples of class III bacteriocins produced by Escherichia coli. Class III bacteriocins also include helveticin $\mathrm{M}$, helveticin J, and enterolysin A produced by Lactobacillus crispatus and Lactobacillus helveticus, respectively (4). Class IV bacteriocins are comprised of lipid or carbohydrate groups (7). Besides, many bacteriocin-producing strains have been found, such as Streptococcus lactis, Listeria monocytogenes (L. monocytogenes), and Staphylococcus aureus (S. aureus) (4).

Lactic acid bacteria (LAB) are food-grade microorganisms recognized by the Food and Drug Administration (FDA). Recently, the isolation of bacteriocins has become a research hotspot. The most well-known bacteriocin produced by LAB is nisin (8). It is an FDA-approved and generally regarded as safe (GRAS) peptide with recognized potential for food preservation, which has been commercialized in more than 50 countries (9). Nisin was effective in the treatment of dental caries and ulcers in humans, and mastitis in cattle $(8,10)$.

Studies on the mode of action and target of bacteriocins can lay a foundation for its applications. The action mode of bacteriocins can generally be grouped into two types. The first one is acting on the cell membrane of the bacteria, which can be further divided into two subclasses: targeting cell membrane protein (11) and non-specific "membrane perforation." Nisin can inhibit the growth of Gram-positive bacteria through two antibacterial mechanisms. Lipid II, as a membrane-anchored cell wall precursor, is essential for the biosynthesis of the bacterial cell wall. When nisin binds with lipid II, the biosynthesis of the cell wall is inhibited, resulting in the death of the bacteria (12). Nisin can also cause the loss of proton motive force (PMF) of the cell membrane through the formation of non-selective transmembrane pores at micromolar concentrations (13). The second type is directed to the destruction of non-membrane substances in cells, for example, the target of microcin B17 is DNA gyrase (14).

Although, bacteriocinogenic Lactobacillus Pentosus (L. pentosus) has been isolated from different products such as fermented meat and cereals, there are few reports on the purification of bacteriocin from L. pentosus (15-19). Lactobacillus Pentosus ZFM94 was isolated from the feces of a healthy infant with strong antibacterial activities and probiotic properties (20). In this study, a three-step method was established to purify a novel bacteriocin (pentocin ZFM94) from the cell-free supernatant (CFS) of L. pentosus ZFM94. The antibacterial spectrum and minimum inhibitory concentrations (MICs) of pentocin ZFM94 were determined. Meanwhile, the effects of temperature, $\mathrm{pH}$, and enzyme on the stability of pentocin ZFM94 were studied. Finally, the leakage experiment and agar well-diffusion method were used to explore the action mode of pentocin ZFM94 and its binding site with lipid II.

\section{MATERIALS AND METHODS}

\section{Strains and Culture Conditions}

Lactobacillus pentosus ZFM94 was isolated from the feces of a healthy infant, deposited at the China Center for Type Culture Collection (CCTCC) with the strain number of CCTCC NO: M 2016632, and cultured in de Man, Rogosa, and Sharpe (MRS) broth at $37^{\circ} \mathrm{C}$. The indicator strains are listed in Table $\mathbf{1}$.

\section{Purification of Bacteriocin}

A three-step method, including ammonium sulfate precipitation, Sephadex ${ }^{\mathrm{TM}}$ G-25, and reverse-phase high-performance liquid chromatography (RP-HPLC) were established to purify bacteriocin. Four liters of clarified MRS broth was inoculated (1\%) with L. pentosus ZFM94 and incubated for 18-20 h at $37^{\circ} \mathrm{C}$. The culture was centrifuged (Beckman, USA) at $8,000 \mathrm{rpm}$ and $4^{\circ} \mathrm{C}$ for $20 \mathrm{~min}$. The CFS was precipitated with saturated ammonium sulfate (gradient from 10 to 90\%). The protein precipitations were collected by centrifugation $\left(8,000 \mathrm{rpm}, 4^{\circ} \mathrm{C}\right.$, $20 \mathrm{~min}$ ), dissolved in $50 \mathrm{~mm}$ phosphate buffer saline (PBS, $\mathrm{pH}$ 3.69), and desalted by dialysis (1 kDa cutoff membrane, Sangon, China). The active fractions were purified by Sephadex G-25 (GE Healthcare, $1.6 \times 80 \mathrm{~cm}$ ) equilibrated and eluted with ultrapure water at $1 \mathrm{ml} / \mathrm{min}$. The eluent was collected every $3 \mathrm{~min}$ until no absorbance was detected at $280 \mathrm{~nm}$. Next, the active ingredient was concentrated by a vacuum rotary evaporator (Marin Christ, Germany). Subsequently, it was introduced into the RP-HPLC system (Waters, USA) equipped with a RP C18 column (YMCPack ODS-AQ, $150 \times 20 \mathrm{~mm}$ L.D.). The buffer A was $0.05 \%$ trifluoroacetic acid (TFA)/distilled water (v/v), and buffer B was 0.05\% TFA/acetonitrile (v/v). Gradient elution ranged from 95\% buffer A to $95 \%$ buffer B, with a flow rate of $4.0 \mathrm{ml} / \mathrm{min}$. Fractions with antibacterial activity were analyzed by an analytical RPHPLC system (Waters 2489 Detector, USA) using RP C18 column (YMC-Pack ODS-AQ, $150 \times 4.6$ mm L.D., Japan) after removing acetonitrile by evaporation. Protein concentration was determined by a bicinchoninic acid (BCA) protein assay kit according to the instructions of the manufacturer (Takara, Dalian, China).

\section{Determination of the Molecular Weight of Pentocin ZFM94}

The rough molecular mass of sample fraction with antibacterial activity prepared by RP-HPLC was analyzed by Tricinesodium dodecyl sulfate-polyacrylamide gel electrophoresis (SDS-PAGE) (5\% concentrated glue and 18\% separation glue). The antibacterial activity and a low molecular weight marker were run at $80 \mathrm{~V}$ for $30 \mathrm{~min}$ and $120 \mathrm{~V}$ during the rest of the separation. After completion of the run, the gel was stained with Coomassie Brilliant Blue G-250 and destained by ethyl alcohol acetic acid solution. Matrix-assisted laser desorption/ionization time-of-flight mass spectrometry (MALDI-TOF MS) (ABSciex 5800) was further used to determine the accurate molecular weight of this sample (21), which was operated in positive ion mode. The $\alpha$-cyano-4-hydroxy-cinnamic acid (CHCA) solution was used as the matrix. In brief, $1 \mu \mathrm{l}$ of the sample was dried on 
TABLE 1 | Inhibition spectrum of pentocin ZFM94 against different bacterial indicator strains.

\begin{tabular}{|c|c|c|c|}
\hline Indicator strains & Growth condition & Antimicrobial activity & Sources \\
\hline Micrococcus luteus 10209 & $\mathrm{LB}$ at $30^{\circ} \mathrm{C}$ & ++++ & Laboratory preservation \\
\hline Staphylococcus aureus D48 & $\mathrm{LB}$ at $37^{\circ} \mathrm{C}$ & +++ & Laboratory preservation \\
\hline $\begin{array}{l}\text { Staphylococcus carnosus } \\
\text { pCA44 }\end{array}$ & $\mathrm{LB}$ at $37^{\circ} \mathrm{C}$ & ++ & Laboratory preservation \\
\hline Staphylococcus carnosus pot20 & $\mathrm{LB}$ at $37^{\circ} \mathrm{C}$ & + & Laboratory preservation \\
\hline Listeria monocytogenes LM1 & $\mathrm{LB}$ at $37^{\circ} \mathrm{C}$ & + & Laboratory preservation \\
\hline Bacillus subtilis BAS2 & LB at $37^{\circ} \mathrm{C}$ & - & Laboratory preservation \\
\hline Escherichia coli DH5 $\alpha$ & $\mathrm{LB}$ at $37^{\circ} \mathrm{C}$ & +++ & Laboratory preservation \\
\hline $\begin{array}{l}\text { Salmonella paratyphi-A } \\
\text { CMCC50093 }\end{array}$ & $\mathrm{LB}$ at $37^{\circ} \mathrm{C}$ & - & $\begin{array}{l}\text { National Center for Medical } \\
\text { Culture Collections (CMCC) }\end{array}$ \\
\hline $\begin{array}{l}\text { Salmonella paratyphi-B } \\
\text { CMCC50094 }\end{array}$ & $\mathrm{LB}$ at $37^{\circ} \mathrm{C}$ & - & $\begin{array}{l}\text { National Center for Medical } \\
\text { Culture Collections (CMCC) }\end{array}$ \\
\hline $\begin{array}{l}\text { Salmonella enterica subsp. } \\
\text { enterica ATCC } 14028\end{array}$ & $\mathrm{LB}$ at $37^{\circ} \mathrm{C}$ & + & $\begin{array}{c}\text { American Type Culture Collection } \\
\text { (ATCC) }\end{array}$ \\
\hline $\begin{array}{l}\text { Saccharomyces cerevisiae } \\
\text { SM190 }\end{array}$ & YPD at $28^{\circ} \mathrm{C}$ & + & Laboratory preservation \\
\hline
\end{tabular}

Inhibitory zone diameter (mm): $++++22-25,+++18-21,++14-17,+10-13,-$ no inhibition.

the sample target plate, and then $0.6 \mu \mathrm{l}$ of CHCA was added after natural drying for the MALDI analysis.

\section{Antibacterial Spectrum and MICs of Pentocin ZFM94}

The antibacterial spectrum of pentocin ZFM94 after purification was detected by the agar well-diffusion method (22). Soft agar of each medium was inoculated with $10^{6}$ colony-forming units $(\mathrm{CFU}) / \mathrm{ml}$ of each indicator strain (Table 1 ) and mixed well, and $8 \mathrm{~mm}$ diameter wells were punched with Oxford Cups in the plates. Every well was filled with $100 \mu \mathrm{l}$ of $10 \mu \mathrm{m}$ pentocin ZFM94, and the plates were incubated overnight at $37^{\circ} \mathrm{C}$. The diameter of the inhibition zones $(\mathrm{mm})$ around the wells was measured.

According to the results of the antibacterial spectrum, MICs of pentocin ZFM94 on S. aureus D48, Micrococcus luteus 10209, and $E$. coli $\mathrm{DH} 5 \alpha$ were determined by tube method (23). The concentration gradient was $0,0.10,0.20,0.50,0.875,1.75$, $2.00,2.50,3.00$, and $10.00 \mu \mathrm{m}$. The absorbance was measured by an ultraviolet spectrophotometer (OLYMPUS, Japan). Each concentration was carried out in triplicate.

\section{Stability of Pentocin ZFM94 on pH, Heat, and Enzyme Conditions}

Purified pentocin ZFM94 was prepared at a concentration of $15 \mu \mathrm{g} / \mathrm{m}$ and was used for testing the effects of heat, $\mathrm{pH}$, and enzymes. To determine thermal stability, the purified pentocin ZFM94 was heated to $50,60,70,80,90,100$, and $121^{\circ} \mathrm{C}$ for $30 \mathrm{~min}$, respectively, and then cooled to room temperature. To evaluate the susceptibility of pentocin ZFM94 to different $\mathrm{pH}$ values, the $\mathrm{pH}$ of purified peptide solution was adjusted to $2-10$ using $1 \mathrm{M}$ hydrochloric acid $(\mathrm{HCl})$ and $1 \mathrm{M}$ sodium hydroxide $(\mathrm{NaOH})$, respectively. The above samples were then incubated at $4^{\circ} \mathrm{C}$ for $2 \mathrm{~h}$ and adjusted to an initial $\mathrm{pH}$ of 3.69. For proteolytic enzyme treatments, pentocin ZFM94 was treated with lysozyme, ribonuclease A, lipase, papain, $\alpha$-amylase, $\alpha$ chymotrypsin, pepsin, and trypsin at the final concentration of $1 \mathrm{mg} / \mathrm{ml}$, under the optimal temperature and $\mathrm{pH}$ of each enzyme for $2 \mathrm{~h}$, and then, the $\mathrm{pH}$ was adjusted to initial $\mathrm{pH}$ of 3.69. The activity of residual anti-M. luteus 10209 was calculated by the agar well-diffusion test. An untreated peptide sample was taken as a control.

\section{Analysis of Transmembrane Electrical Potential}

Fluorescence leakage test was used to measure transmembrane electrical potential $(\Delta \Psi)(24)$, and the response value of the cell membrane probe [3, 3-dipropylthiadicarbocyanine iodide, DisC2(5)] was measured by a fluorescence spectrophotometer (Agilent, USA). Luria-Bertani (LB) broth $(20 \mathrm{ml})$ was inoculated with a $1 \%$ overnight culture of $M$. luteus 10209 . The inoculated broth was grown until it reached the exponential phase of growth $\left(\mathrm{OD}_{600}=0.6-0.8\right)$. Cells were collected by centrifugation at 4,000 $\mathrm{rpm}$ and $4^{\circ} \mathrm{C}$ for $30 \mathrm{~min}$, washed twice with buffer $(250 \mathrm{~mm}$ glucose, $5 \mathrm{~mm}$ magnesium sulfate $\left(\mathrm{MgSO}_{4}\right), 10 \mathrm{~mm}$ tripotassium phosphate $\left(\mathrm{K}_{3} \mathrm{PO}_{4}\right)$, and $100 \mathrm{~mm}$ potassium chloride $(\mathrm{KCl}), \mathrm{pH}$ 7.0), and dissolved in $2 \mathrm{ml}$ of the same buffer, by adding 20 $\mu \mathrm{l}$ strain and $2 \mu \mathrm{l}$ DisC2(5) into $2 \mathrm{ml}$ buffer in order. When the detected fluorescence value was stable, pentocin ZFM94 with final concentrations of 1.75 and $8.75 \mu \mathrm{m}$ was added, respectively. The same volume of $0.05 \%$ acetic acid was used as a negative control.

\section{Study on the Binding of Pentocin ZFM94 to Lipid II}

Studies have shown that lipid II was the target of nisin (25), and the combination of lipid II and nisin can mediate the formation of pores. Nisin and pentocin ZFM94 were mixed with lipid II, respectively. The final concentration of nisin or pentocin ZFM94 was $10 \mu \mathrm{m}$, while the concentration of lipid II was $20 \mu \mathrm{m}$. The 


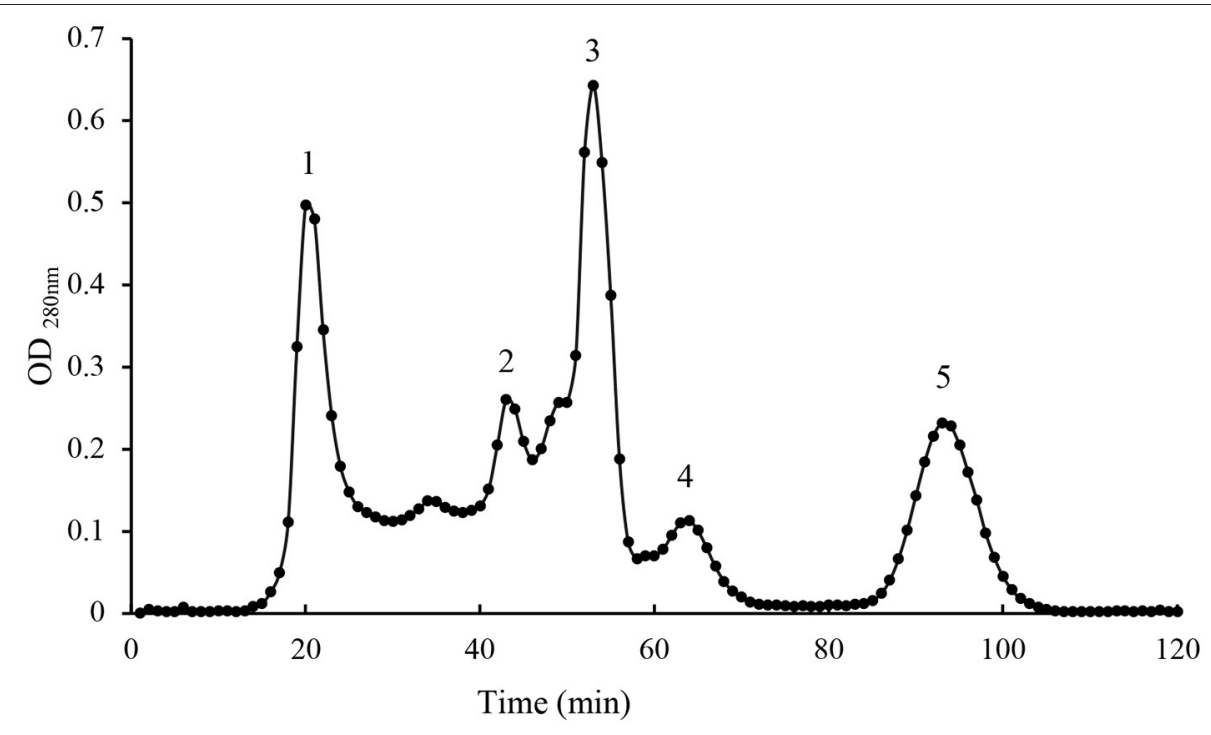

FIGURE 1 | Gel filtration chromatography peak of active fractions.

mixture was maintained at $4^{\circ} \mathrm{C}$ for $1 \mathrm{~h}$. The changes in the antibacterial activity were detected by the agar well-diffusion method. Micrococcus luteus 10209 was used as the indicator. Then, the size of the inhibition zone was observed.

\section{RESULTS}

\section{Purification of Bacteriocin}

Pentocin ZFM94 was purified from a $4 \mathrm{~L}$ culture supernatant. The obtained precipitate had good antibacterial activity when the saturation of ammonium sulfate was $40 \%$. Then, Sephadex G25 was used to separate and acquire the range between 1 and $5 \mathrm{kDa}$. Ultrapure water was used as a buffer. When the sample was added to the dextran gel chromatography, it was separated according to the molecular weight. About $40 \%$ ammonium sulfate precipitation component can be well-separated from Sephadex G-25. Five peaks were obtained as shown in Figure 1. Only peak 3 had antibacterial activity against M. luteus 10209 .

After purification by Sephadex G-25, RP-HPLC was used to purify the active ingredient. The active ingredient was obtained at a retention time of 22-23 min using the preparative C18 column. Analytical column C18 was used to analyze bacteriocin, and only a single peak at 34.129 min was observed, as shown in Figure 2 . The purity of bacteriocin obtained by the area normalization method was $98.70 \%$. The concentration of bacteriocin was $3.65 \mathrm{mg} / \mathrm{L}$.

\section{Molecular Weight Determination of Purified Bacteriocin}

As we can see from the result of Sephadex G-25, the molecular weight of purified bacteriocin was $<5 \mathrm{kDa}$. Tricine-SDS-PAGE analysis was performed with purified bacteriocin. The molecular mass determined by relative mobility was between 1.7 and 4.6 $\mathrm{kDa}$. Purified bacteriocin had an accurate molecular mass of
3,547.74 Da by MALDI-TOF MS as shown in Figure 3 and named pentocin ZFM94.

\section{Antimicrobial Spectrum and MICs}

Pentocin ZFM94 showed the inhibitory effects against most Gram-positive bacteria, some Gram-negative bacteria, and fungi, as shown in Table 1. Among the indicator species, pentocin ZFM94 showed high activities against M. luteus 10209, S. aureus D48, and E. coli DH5 $\alpha$. In addition, it inhibited L. monocytogenes LM1, Salmonella enterica subsp. enterica ATCC14028, and Saccharomyces cerevisiae SM190. However, pentocin ZFM94 had no inhibitory activity against Bacillus subtilis BAS2, Salmonella paratyphi-B CMCC50094, and Salmonella paratyphiA CMCC50093. Pentocin ZFM94 also inhibited Gram-positive bacteria S. carnosus pot20 and L. monocytogenes LM1, and Saccharomyces cerevisiae SM190. These results demonstrated that this bacteriocin had a broad antibacterial activity.

Minimal inhibitory concentrations were determined by the test tube method (23). Values of MICs for M. luteus 10209, S. aureus D48, and E. coli DH5 $\alpha$ were $1.75,2.00$, and $2.50 \mu \mathrm{m}$, respectively, which exhibited obvious antibacterial activities.

\section{The Effects of pH, Temperature, and Enzymes on Pentocin ZFM94}

Pentocin ZFM94 had the best bacteriostatic effect at $\mathrm{pH} 3$ and $\mathrm{pH}$ 6; when the $\mathrm{pH}$ increased from 8 to 10 , the inhibition activity was significantly declined. Pentocin ZFM94 maintained complete activity after exposure from 50 to $80^{\circ} \mathrm{C}$ for $30 \mathrm{~min}$ (Figure 4A). When the temperature was higher than $80^{\circ} \mathrm{C}$, the inhibition activity was significantly descended. The effects of enzymes were presented in Figure 4B. The activity of pentocin ZFM94 was significantly reduced by treatment with pepsin and trypsin. However, amylase, lysozyme, lipase, and ribonuclease A did not effect on the antimicrobial activity. 


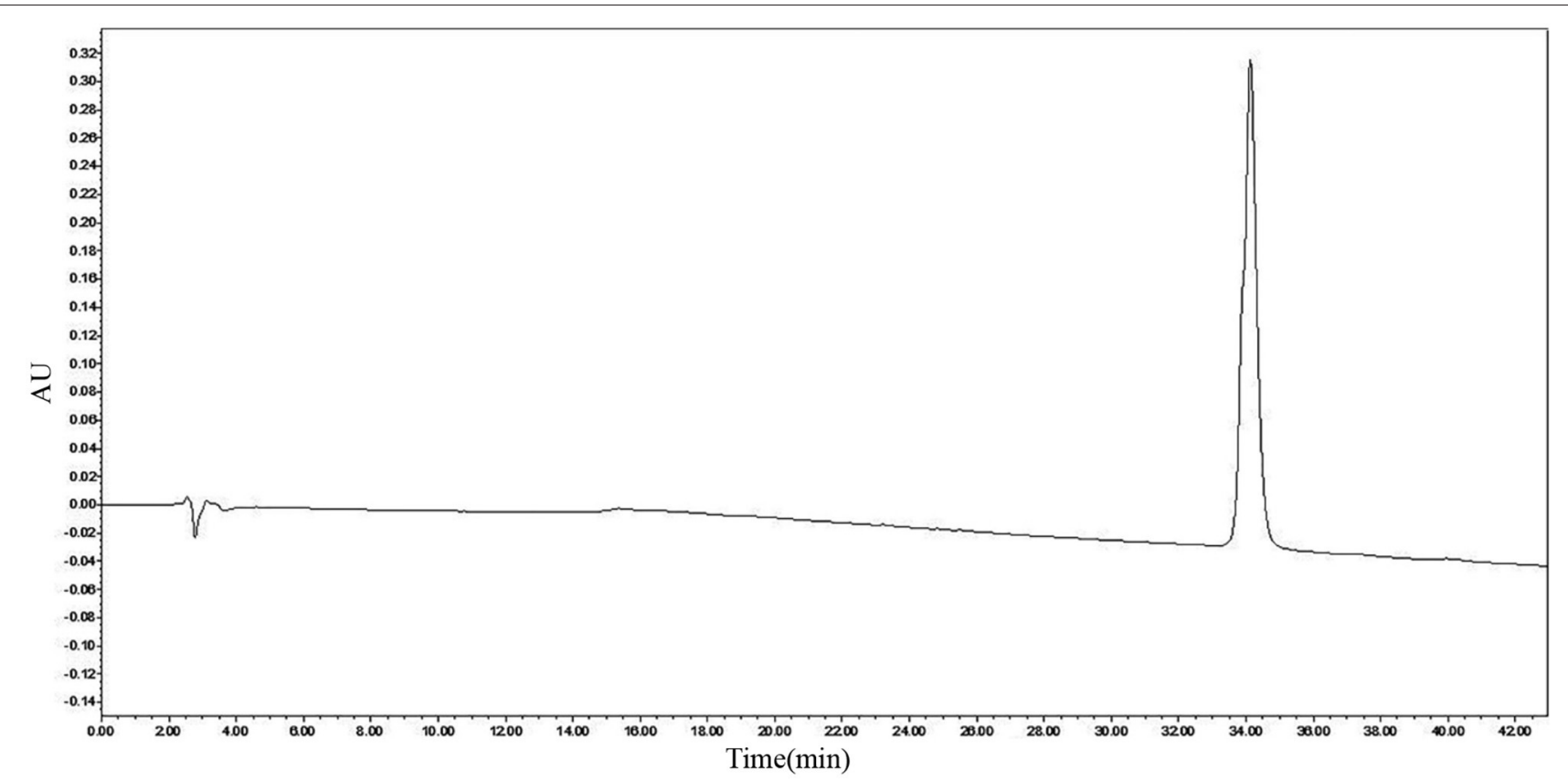

FIGURE 2 | Reverse-phase high-performance liquid chromatography (RP-HPLC) analysis of pentocin ZFM94.

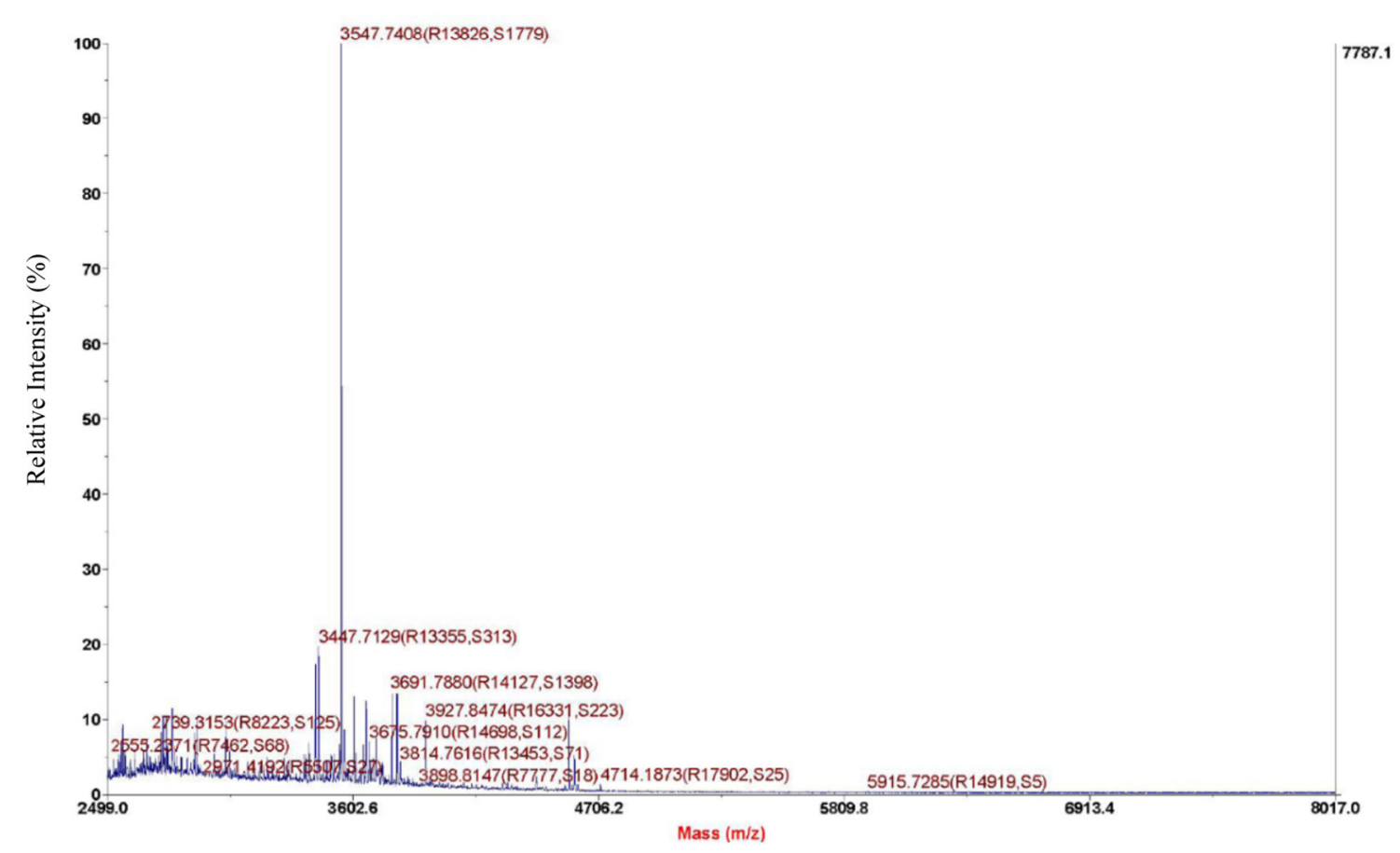

FIGURE 3 | Molecule weight of pentocin ZFM94 determined by matrix-assisted laser desorption/ionization time-of-flight mass spectrometry (MALDI-TOF MS).

\section{Antibacterial Action Mode of Pentocin ZFM94}

The effect of pentocin ZFM94 on the membrane integrity of $M$. luteus 10209 was determined by the membrane potential sensitive dye DisC2(5). After the addition of DisC2(5), the fluorescence value decreased and reached stability in $3 \mathrm{~min}$.
When $0.05 \%$ acetic acid was added, the fluorescence value did not change. As shown in Figure 5, with the addition of pentocin ZFM94 at a final concentration of $8.75 \mu \mathrm{m}(5 \times \mathrm{MIC})$, the fluorescence value increased faster than the final concentration of $1.75(1 \times \mathrm{MIC})$. It can be seen that the antibacterial action of pentocin ZFM94 was through the perforation of the bacterial 


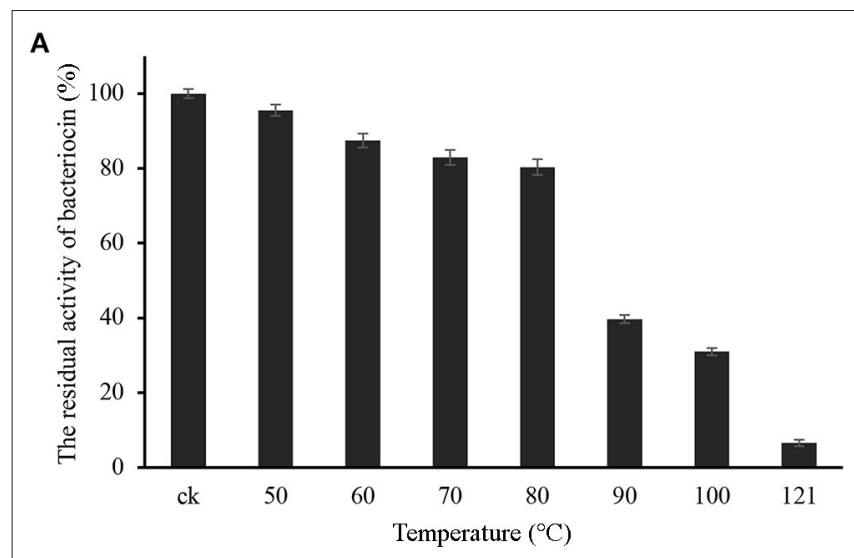

B

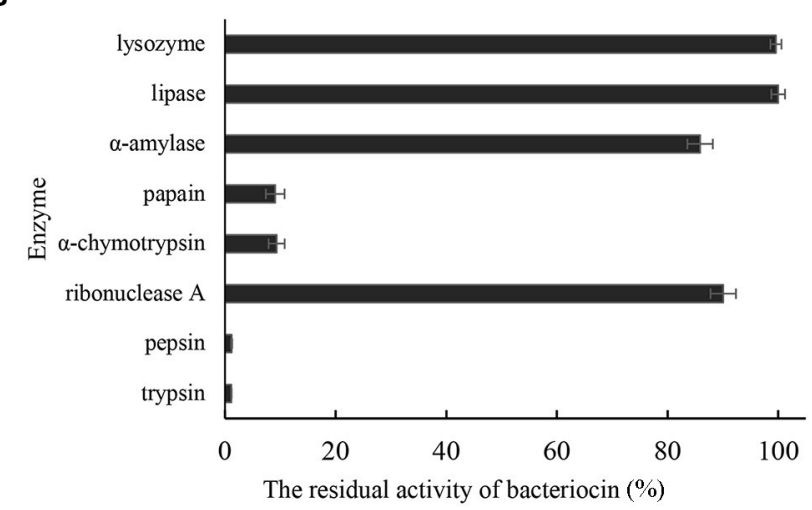

FIGURE 4 | (A) Effect of temperature on the antibacterial activity of pentocin ZFM94; (B) Stability of pentocin ZFM94 after different enzyme treatments.

membrane, and indicator bacteria were killed by causing leakage of intracellular electrolytes.

In order to further explore whether lipid II was the target of pentocin ZFM94, nisin was used as a control and M. luteus 10209 was used as an indicator. The lipid II $(20 \mu \mathrm{m})$ was mixed at a ratio of 2:1 with the pentocin ZFM94 $(10 \mu \mathrm{m})$. The bacteriostatic activity was detected by the agar well-diffusion method as shown in Figure 6. After pentocin ZFM94 was mixed with lipid II, the inhibitory action of penticin ZFM94 did not change, but the antibacterial effect of nisin disappeared. The result showed that lipid II was not the target of pentocin ZFM94.

\section{DISCUSSION}

Bacteriocins are generally defined as a class of small molecular proteins or peptides synthesized by ribosomes in the metabolic process of some bacteria. Lactobacillus Pentosus has antibacterial activity, which is mainly related to its metabolites (26), and bacteriocin is one of them. Lactobacillus Pentosus can produce bacteriocin that has been reported, pentocin MQ1 produced by L. pentosus CS2 (19), and pentocin TV35b produced by $L$. pentosus TV35b (27). The appropriate separation and purification processes vary from different bacteriocins. Pentocin TV $35 \mathrm{~b}$ was purified by ammonium sulfate precipitation, followed by sulfopropyl (SP)-sepharose cation exchange chromatography (27). Pentocin JL-1 was purified using macroporous resin, cation exchange, gel filtration, and semipreparative HPLC (17). Pentocin MQ1 was purified using the adsorptiondesorption approach followed by RP-HPLC (19). In our study, pentocin ZFM94 was purified by a three-step process, including ammonium sulfate saturation at 40\%, Sephadex G-25, and RPHPLC from the supernatant of L. pentosus ZFM94. Then, we determined its molecular weight, determined its antibacterial spectrum, and explored its antibacterial mode.

Pentocin ZFM94 exhibited high thermal and $\mathrm{pH}$ stability. It retained $80.37 \%$ of its original antibacterial activity after heating at $80^{\circ} \mathrm{C}$ for $30 \mathrm{~min}$. The antibacterial activity of pentocin ZFM94 was stable at $\mathrm{pH} 2-7$. Pentocin MQ1 retained activity at 40$121^{\circ} \mathrm{C}$, but unlike pentocin ZFM94, it was inactive at $\mathrm{pH}$ 6-7 (19). Nisin also exhibited a strong antibacterial activity at low $\mathrm{pH}$, but it will be inactivated at pH close to 7 (28). Pentocin ZFM94 was sensitive to trypsin and pepsin, but not to amylase, lysozyme, lipase, and ribonuclease A. Studies have reported that leuconocin $\mathrm{S}$ and carnocin 54 are sensitive to amylase but are not sensitive to protease (29). Thus, pentocin ZFM94 has a proteinaceous nature like most other bacteriocins.

Pentocin ZFM94 performed activity against Gram-positive bacteria, Gram-negative bacteria, and fungi, especially for $S$. aureus D48, M. luteus 10209, and E. coli DH5 $\alpha$. Many pentocins produced from $L$. pentosus also can inhibit a variety of Grampositive bacteria, Gram-negative bacteria, and the fungi Candida albicans (27). Food spoilage caused by microbial contamination has been a huge challenge for production for the food industry. But so far, only nisin was allowed to be used as a food preservative. Nisin only can inhibit Gram-positive bacteria, and plantaricin 163 can inhibit Gram-positive and Gram-negative bacteria but cannot inhibit fungi (30). Most bacteriocins could not be widely and effectively used in the food industry due to their narrow spectrum and exhibit inhibitory activity against only genetically close bacteria. Therefore, pentocin ZFM94 has a wider application prospect. The MICs of pentocin ZFM94 against $S$. aureus D48, M. luteus 10209, and E. coli DH5 $\alpha$ were 2.00, 1.75, and $2.50 \mu \mathrm{m}$. BMA has a molecular weight of $1.77 \mathrm{kDa}$ produced by L. crustorum MN047, and MICs toward S. aureus ATCC 29213 and E. coli ATCC 25922 were 165 and $305 \mu \mathrm{m}$, respectively (21). Pentocin ZFM94 performed a higher activity against $S$. aureus and $E$. coli than bacteriocin BMA.

The mode of action of many bacteriocins has been identified to inhibit microorganisms by disrupting the cell membrane integrity of microorganisms $(31,32)$. In our study, $1 \times$ and $5 \times$ MIC of pentocin ZFM94 were tested using a fluorescence leakage test. Both concentrations of pentocin ZFM94 were able to disrupt the integrity of $M$. luteus 10209 cell membrane. In addition, the disruption of cell membrane integrity was dose dependent. Similar dose-dependent inhibitory action has also been observed by aureocin A53 (32) and Plantaricin EF (Pln EF) (21). However, whether it is a specific membrane perforation still needs further study. Pediocin PA-1 (33) and Lactococcin G (34) all have specific membrane perforation mechanisms.

The mode of action of bacteriocin is not unique. Nisin not only has specific membrane perforation but also can mediate the formation of the hole by combining with lipid II. Studies also 


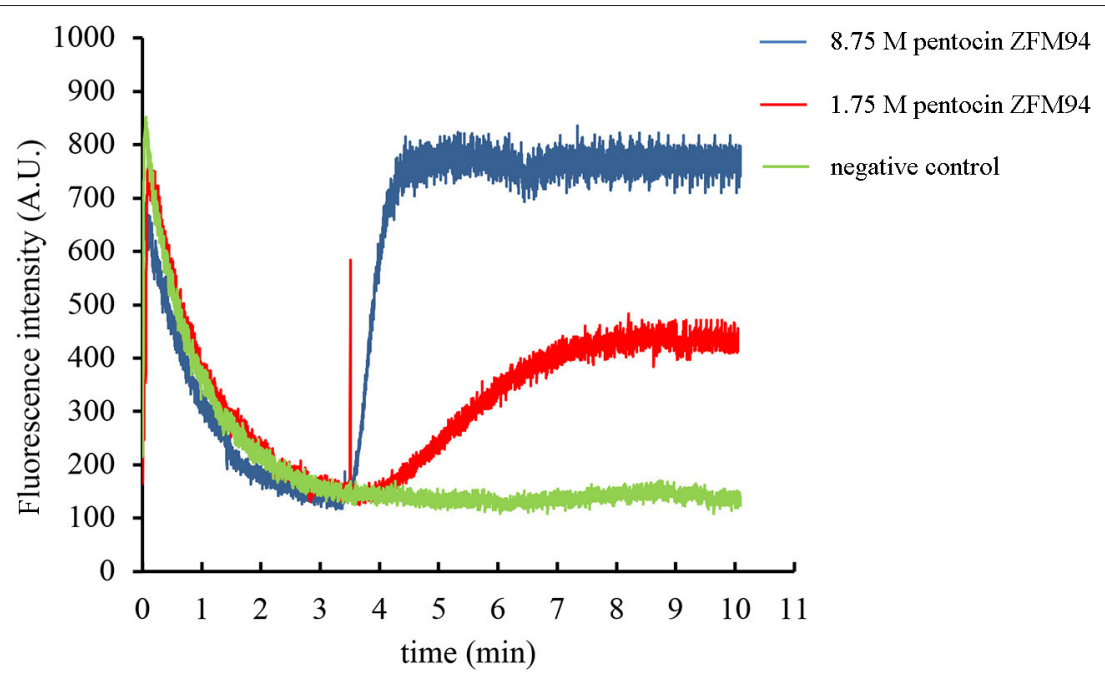

FIGURE 5 | Effect of different pentocin ZFM94 concentrations on the membrane of Micrococcus luteus (M. Iuteus).

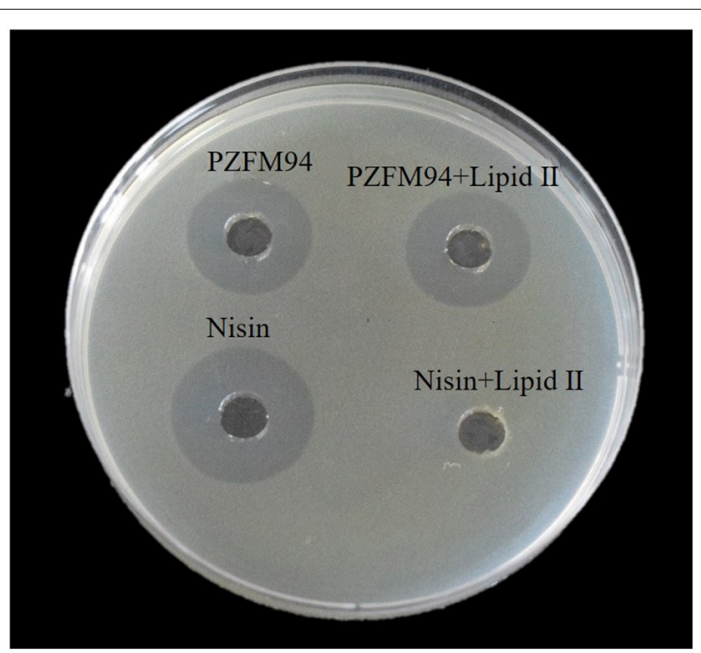

FIGURE 6 | Binding experiment of pentocin ZFM94 with lipid II.

found that lipid II was the target of many bacteriocins, such as nisin (12), mersacidin (35), and plantaricin C (36). The molar ratio 1:2 of pentocin ZFM94 and lipid II was studied using the agar well-diffusion test. After pentocin ZFM94 was mixed with lipid II, the inhibitory action did not change suggesting that lipid II is not the target of pentocin ZFM94.

In future studies, we will further optimize the purification method of pentocin ZFM94 and increase the recovery of it. The

\section{REFERENCES}

1. Cotter PD, Ross RP, Hill C. Bacteriocins - a viable alternative to antibiotics? Nat Rev Microbiol. (2013) 11:95-105. doi: 10.1038/nrmicro2937

2. Reddy KVR, Yedery RD, Aranha C. Antimicrobial peptides: premises and promises. Int J Antimicrob Agents. (2004) 24:53647. doi: 10.1016/j.ijantimicag.2004.09.005 target of the action, the amino acid sequence, and the structure of pentocin ZFM94 will be addressed in more detail.

\section{DATA AVAILABILITY STATEMENT}

The original contributions generated for the study are included in the article/supplementary material, further inquiries can be directed to the corresponding author/s.

\section{AUTHOR CONTRIBUTIONS}

QG, PL, and QZ conceived and designed the study. LX, MD, and YL completed the experiment. MD and DW conducted analysis the results and finished the paper. All authors contributed to the article and approved the submitted version.

\section{FUNDING}

This project was funded by the National Natural Science Foundation of China (No. U20A2066), the Key Research and Development Program of Zhejiang Province (No. 2020C04002), and the Natural Science Foundation of Zhejiang Province (No. LZ21C200001).

\section{ACKNOWLEDGMENTS}

We would like to thank Eefjan Breukink (Utrecht University, the Netherlands) for providing lipid II.

3. Chatterjee S, Chatterjee S, Lad SJ, Phansalkar MS, Rupp RH, Ganguli BN, et al. Mersacidin, a new antibiotic from Bacillus fermentation, isolation, purification and chemical characterization. J Antibiot. (1992) 45:8328. doi: 10.7164/antibiotics.45.832

4. Kumariya R, Garsa AK, Rajput YS, Sood SK, Akhtar N, Patel S. Bacteriocins: classification, synthesis, mechanism of action, and resistance development in food spoilage causing bacteria. 
Microb Pathogen. (2019) 128:171-7. doi: 10.1016/j.micpath.2019. 01.002

5. Eijsink VGH, Axelsson L, Diep DB, Håvarstein LS, Holo H, Nes IF. Production of class II bacteriocins by lactic acid bacteria; an example of biological warfare and communication. Antonie van Leeuwenhoek. (2002) 81:63954. doi: $10.1023 / \mathrm{A}: 1020582211262$

6. Garneau S, Martin NI, Vederas JC. Two-peptide bacteriocins produced by lactic acid bacteria. Biochimie. (2002) 84:577592. doi: 10.1016/S0300-9084(02)01414-1

7. Klaenhammer T. Genetics of bacteriocins produced by lactic acid bacteria. FEMS Microbiol Rev. (1993) 12:39-85. doi: 10.1016/0168-6445(93)90057-G

8. Delves-Broughton J, Blackburn P, Evans RJ, Hugenholtz J. Applications of the bacteriocin, nisin. Antonie van Leeuwenhoek. (1996) 69:193202. doi: $10.1007 /$ BF00399424

9. Garsa AK, Kumariya R, Sood SK, Kumar A, Kapila S. Bacteriocin production and different strategies for their recovery and purification. Probiotics Antimicro Prot. (2014) 6:47-58. doi: 10.1007/s12602-013-9153-z

10. Severina E, Severin A, Tomasz A. Antibacterial efficacy of nisin against multidrug-resistant Gram- positive pathogens. J Antimicrob Chemother. (1998) 41:341-7. doi: 10.1093/jac/41.3.341

11. Kjos M, Borrero J, Opsata M, Birri DJ, Holo H, Cintas LM, et al. Target recognition, resistance, immunity and genome mining of class II bacteriocins from gram-positive bacteria. Microbiology. (2011) 157:325667. doi: $10.1099 / \mathrm{mic} .0 .052571-0$

12. Breukink E. Use of the cell wall precursor lipid II by a pore-forming peptide antibiotic. Science. (1999) 286:2361-4. doi: 10.1126/science.286.5448.2361

13. Aarti C, Khusro A, Arasu MV, Agastian P, Al-Dhabi NA. Biological potency and characterization of antibacterial substances produced by Lactobacillus pentosus isolated from Hentak, a fermented fish product of North-East India. Springerplus. (2016) 5:1743. doi: 10.1186/s40064-016-3452-2

14. Parks WM, Bottrill AR, Pierrat OA, Durrant MC, Maxwell A. The action of the bacterial toxin, microcin B17, on DNA gyrase. Biochimie. (2007) 89:500-7. doi: 10.1016/j.biochi.2006.12.005

15. Delgado A, Brito D, Peres C, Noé-Arroyo F, Garrido-Fernández A. Bacteriocin production by Lactobacillus pentosus $\mathrm{B} 96$ can be expressed as a function of temperature and $\mathrm{NaCl}$ concentration. Food Microbiol. (2005) 22:5218. doi: 10.1016/j.fm.2004.11.015

16. Guerreiro J, Monteiro V, Ramos C, de Melo Franco BDG, Martinez RCR, Todorov SD, et al. Lactobacillus pentosus B231 isolated from a Portuguese PDO cheese: production and partial characterization of its bacteriocin. Probiotics Antimicro Prot. (2014) 6:95-104. doi: 10.1007/s12602-014-9157-3

17. Jiang H, Zou J, Cheng H, Fang J, Huang G. Purification, characterization, and mode of action of pentocin JL-1, a novel bacteriocin isolated from Lactobacillus pentosus, against drug-resistant Staphylococcus aureus. BioMed Res Int. (2017) 2017:1-11. doi: 10.1155/2017/7657190

18. Todorov SD, Vaz-Velho M, Gibbs P. Comparison of two methods for purification of plantaricin ST31, a bacteriocin produced by Lactobacillus plantarum ST31. Braz J Microbiol. (2004) 35:157-60. doi: 10.1590/S1517-83822004000100026

19. Wayah SB, Philip K. Pentocin MQ1: a novel, broad-spectrum, poreforming bacteriocin from Lactobacillus pentosus CS2 with quorum sensing regulatory mechanism and biopreservative potential. Front Microbiol. (2018) 9:564. doi: 10.3389/fmicb.2018.00564

20. Ye K, Li P, Gu Q. Complete genome sequence analysis of a strain Lactobacillus pentosus ZFM94 and its probiotic characteristics. Genomics. (2020) 112:31429. doi: 10.1016/j.ygeno.2020.05.015

21. Yi L, Dang Y, Wu J, Zhang L, Liu X, Liu B, et al. Purification and characterization of a novel bacteriocin produced by Lactobacillus crustorum MN047 isolated from koumiss from Xinjiang, China. J Dairy Sci. (2016) 99:7002-15. doi: 10.3168/jds.2016-11166

22. Tagg JR, McGiven AR. Assay system for bacteriocins. Appl Microbiol. (1971) 21:943. doi: 10.1128/am.21.5.943-943.1971

23. Bédard F, Hammami R, Zirah S, Rebuffat S, Fliss I, Biron E. Synthesis, antimicrobial activity and conformational analysis of the class IIa bacteriocin pediocin PA-1 and analogs thereof. Sci Rep. (2018) 8:9029. doi: $10.1038 / \mathrm{s} 41598-018-27225-3$
24. Ladokhin AS, Selsted ME, White SH. Sizing membrane pores in lipid vesicles by leakage of co-encapsulated markers: pore formation by melittin. Biophys J. (1997) 72:1762-6. doi: 10.1016/S0006-3495(97)78822-2

25. Jiang H, Tang X, Zhou Q, Zou J, Li P, Breukink E, et al. Plantaricin NC8 from Lactobacillus plantarum causes cell membrane disruption to Micrococcus luteus without targeting lipid II. Appl Microbiol Biotechnol. (2018) 102:746573. doi: $10.1007 /$ s00253-018-9182-3

26. Lipińska L, Klewicki R, Sójka M, Bonikowski R, Zyzelewicz D, Kołodziejczyk $\mathrm{K}$, et al. Antifungal activity of Lactobacillus pentosus ŁOCK 0979 in the presence of polyols and galactosyl-polyols. Probiotics Antimicro Prot. (2018) 10:186-200. doi: 10.1007/s12602-017-9344-0

27. Okkers DJ, Dicks LMT, Silvester M, Joubert JJ, Odendaal HJ. Characterization of pentocin TV35b, a bacteriocin-like peptide isolated from Lactobacillus pentosus with a fungistatic effect on Candida albicans. J Appl Microbiol. (1999) 87:726-34. doi: 10.1046/j.1365-2672.1999.00918.x

28. Garcera MJG, Elferink MGL, Driessen AJM, Konings WN. In vitro pore-forming activity of the lantibiotic nisin. Role of protonmotive force and lipid composition. Eur J Biochem. (1993) 212:417-22. doi: 10.1111/j.1432-1033.1993.tb17677.x

29. Budde B. Leuconostoc carnosum 4010 has the potential for use as a protective culture for vacuum-packed meats: culture isolation, bacteriocin identification, and meat application experiments. Int J Food Microbiol. (2003) 83:17184. doi: 10.1016/S0168-1605(02)00364-1

30. Hu M, Zhao H, Zhang C, Yu J, Lu Z. Purification and characterization of plantaricin 163, a novel bacteriocin produced by Lactobacillus plantarum 163 isolated from traditional chinese fermented vegetables. J Agric Food Chem. (2013) 61:11676-82. doi: 10.1021/jf403370y

31. Huang HW, Chen F-Y, Lee M-T. Molecular mechanism of peptide-induced pores in membranes. Phys Rev Lett. (2004) 92:198304. doi: 10.1103/PhysRevLett.92.198304

32. Netz DJA, Bastos Mdo C, Sahl H-G. Mode of action of the antimicrobial peptide aureocin a53 from staphylococcus aureus. AEM. (2002) 68:527480. doi: 10.1128/AEM.68.11.5274-5280.2002

33. Zhao H, Mattila J-P, Holopainen JM, Kinnunen PKJ. Comparison of the membrane association of two antimicrobial peptides, magainin 2 and indolicidin. Biophys J. (2001) 81:297991. doi: 10.1016/S0006-3495(01)75938-3

34. Paiva AD, Breukink E, Mantovani HC. Role of lipid II and membrane thickness in the mechanism of action of the lantibiotic bovicin HC5. Antimicrob Agents Chemother. (2011) 55:528493. doi: 10.1128/AAC.00638-11

35. Brötz H, Bierbaum G, Leopold K, Reynolds PE, Sahl H-G. The lantibiotic mersacidin inhibits peptidoglycan synthesis by targeting Lipid II. Antimicrob Agents Chemother. (1998) 42:154-60. doi: 10.1128/AAC.42.1.154

36. Wiedemann I, Böttiger T, Bonelli RR, Schneider T, Sahl H-G, Martínez B. Lipid II-based antimicrobial activity of the lantibiotic plantaricin C. AEM. (2006) 72:2809-14. doi: 10.1128/AEM.72.4.2809-2814.2006

Conflict of Interest: The authors declare that the research was conducted in the absence of any commercial or financial relationships that could be construed as a potential conflict of interest.

Publisher's Note: All claims expressed in this article are solely those of the authors and do not necessarily represent those of their affiliated organizations, or those of the publisher, the editors and the reviewers. Any product that may be evaluated in this article, or claim that may be made by its manufacturer, is not guaranteed or endorsed by the publisher.

Copyright (๑) 2021 Dai, Li, Xu, Wu, Zhou, Li and Gu. This is an open-access article distributed under the terms of the Creative Commons Attribution License (CC BY). The use, distribution or reproduction in other forums is permitted, provided the original author(s) and the copyright owner(s) are credited and that the original publication in this journal is cited, in accordance with accepted academic practice. No use, distribution or reproduction is permitted which does not comply with these terms. 